\title{
Leaf-cutting ants, seasonal burning and nutrient distribution in Cerrado vegetation
}

\author{
LEANDRO SOUSA-SOUTO, ${ }^{1}$ JOSÉ H. SCHOEREDER ${ }^{2 \star}$ AND \\ CARLOS E. G. R. SCHAEFER ${ }^{3}$ \\ ${ }^{1}$ Programa de Pós-Graduação em Entomologia, Departmento de Biologia Animal, Universidade Federal \\ de Viçosa, ${ }^{2}$ Departmento de Biologia Geral, Universidade Federal de Viçosa, Brazil (Email: \\ jschoere@ufv.br), and ${ }^{3}$ Departmento de Solos, Universidade Federal de Viçosa, Brazil
}

\begin{abstract}
Fire and herbivory are known to modify plant community structure. Many studies have suggested that fire ashes may increase soil nutrients in dystrophic soils. Herbivores may also change plant community structure through direct effects of herbivory and affecting nutrient cycling. Leaf-cutting ants were traditionally viewed as herbivores, although their role may be more complex, because their nests affect both chemical and physical soil properties, thus affecting plants indirectly. We investigated the effects of frequent burning and of leaf-cutting ants on the nutrient status of an herbaceous and a shrub species occurring in the Brazilian Cerrado, a habitat that is characterized by natural burnings. The proximity of ant nests resulted in an increase of nutrients in the leaves of both vegetation strata, whereas burning sometimes resulted in a decrease of nutrients. Our results do not lead to a possible positive effect of fire on plant nutrient content. On the other hand, ant nests may represent an important source of nutrients for plants on the nutrient-depleted Cerrado soils and may accelerate vegetation recovery after burning.
\end{abstract}

Key words: Atta laevigata, Echinolaena inflexa, nutrient supply, savanna, Solanum lycocarpum.

\section{INTRODUCTION}

The structure of plant communities is directly affected by biotic and abiotic environmental factors. Fire is one of these environmental factors; it is common in the tropics and has considerable effects on ecosystem structure, species composition and nutrient cycling (Coutinho 1978; Crutzen \& Andreae 1990). Fire can act as a mineralizing agent and can increase the shortterm availability of nutrients for plant growth (Van de Vijver et al. 1999), although long-term productivity is negatively affected through nutrient loss (Kauffman et al. 1994). In systems with nutrient-poor soils, such as tropical savannas, the high nutrient concentration in post-burn vegetation is thought to be principally caused by enhanced soil nutrient supply through ashes (Batmanian \& Haridasan 1985; Cook 1994).

Fire can also have indirect effects on nutrient cycling through effects on herbivores and soil mesofauna, changing their density, biomass and spatial distribution. Insect herbivores have a trend to concentrate in post-burned areas, and this tendency is likely to be related to a higher nutrient concentration in plant post-fire regrowth (Radho-Toly et al. 2001). This indirect effect of fire could create a strong top-down

*Corresponding author.

Accepted for publication January 2007. effect of herbivorous insects on plant communities. Unfortunately, few empirical data, to our knowledge, directly tested this assertion (Radho-Toly et al. 2001).

The Brazilian Cerrado comprises a complex vegetation mosaic of savannas, grasslands and dry forests with fires occurring every 1-3 years (Eiten 1972). Although plants differ widely in their tolerance to fire and their capacity to recover afterwards, virtually all plants that occur in the Cerrado have evolved to tolerate, survive and sometimes even depend on fire for their reproductive success (Coutinho 1990). Thus, together with seasonal rainfall and low-nutrient soil, frequent burning is probably one of the most important factors for the persistence of the Cerrado in Central Brazil (Coutinho 1990).

Most burnings in the Cerrado are concentrated in the dry season (May to September) and its main effect is the removal of old, dead vegetation, which is replaced by young regrowth. Post-fire regrowth, however, is not fast, so the landscape remains uncovered by vegetation until the start of the rainy season. These vegetation gaps can facilitate establishment by leaf-cutting ants, which prefer open terrain. Disturbed, recently burned areas invariably have high nest densities (Schoereder \& Coutinho 1990; Vasconcelos \& Cherrett 1995). Like fire, leaf-cutting ants play an important role in the ecosystem; they also affect plant diversity and nutrient cycling (Lugo et al. 1973; 
Haines 1978; Moutinho et al. 2003; Farji-Brener \& Ghermandi 2004). Hence, fire has a direct effect on nutrient cycling through ashes, and an indirect effect through the facilitation of colonization of leaf-cutting ants, whereas leaf-cutting ants directly affect nutrient cycling through herbivory and indirectly by changes in soil properties.

Most leaf-cutting ant species of the Atta genus build and maintain large colonies in Cerrado soils, with nests covering more than $250 \mathrm{~m}^{2}$ and being several meters deep (Autuori 1947; Coutinho 1984; Hölldobler \& Wilson 1990). The excavation of nests by these ants promotes physical and chemical modifications in the soil (Coutinho 1984; Moutinho et al. 2003; Verchot et al. 2003). Subterraneous chambers containing fungal gardens or garbage are storages of organic matter, where nutrient availability is enhanced and this is accompanied by soil inversion by channel excavation. This picture is valid to most leaf-cutting ant species, although Atta colombica and some species of the genus Acromyrmex deposit their garbage in soil surface (Farji-Brener \& Medina 2000).

Several studies have investigated effects of fire (Kauffman et al. 1994; Van de Vijver et al. 1999; Moreira 2000) and leaf-cutting ants (Jonkman 1978; Farji-Brener \& Illes 2000) on plant communities, but up to now, no studies have investigated these two factors simultaneously. Coutinho (1984) suggested that leaf-cutting ants and fire play an antagonistic role in nutrient cycling in the Cerrado of Brazil. He hypothesized that, owing to the low-nutrient soil, postfire regrowth of woody plant vegetation may be very difficult if an adequate nutrient supply is not available to roots. Active nests of leaf-cutting ants could act as nutrient sources for woody plants owing to high nest density in burned areas. Thus, fire may favour herbaceous vegetation by ash deposition whereas the presence of active leaf-cutting ants favours woody plants

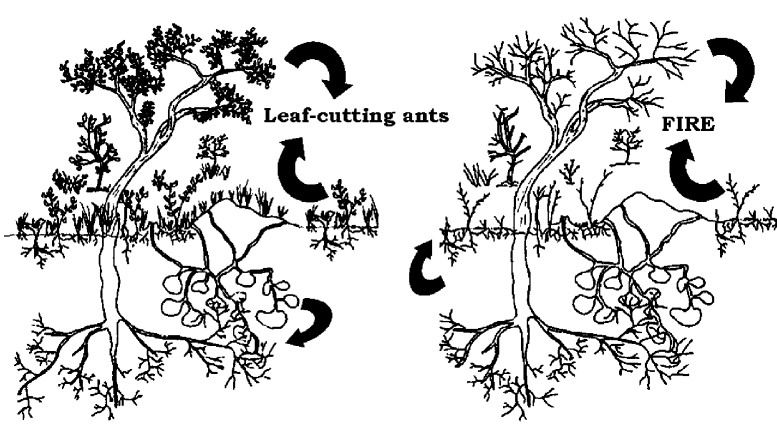

Fig. 1. The hypothetical antagonistic effect of leaf-cutting ants and fire on nutrient cycling in a Cerrado vegetation. Herbaceous plants are thought to benefit from fire ashes in burned areas, whereas leaf-cutting ants are thought to favour woody plants through deposition of organic matter in the nests. Arrows indicate the nutrient direction in the biogeochemical cycle (adapted from Coutinho 1984). because of the deposition of organic matter (Fig. 1). This hypothesis has not been explicitly tested yet. Coutinho's hypothesis suggests that the nutrient status of herbaceous plants will be increased in burned areas relative to plants in unburned areas, independent of the presence of ant nests. In contrast, a higher nutrient status of woody plants is expected closer to Atta nests, and lower nutrient concentrations are expected in woody plants from burned areas.

We tested these predictions on the antagonistic effects of leaf-cutting ants and fire on nutrient status of herbs and shrubs, using the ant species Atta laevigata F. Smith (1858), the shrub Solanum lycocarpum (Solanaceae) and the herbaceous species Echinolaena inflexa (Poaceae). These species are indigenous in the Cerrado and the plants are commonly found together on active $A$. laevigata nests mounds.

\section{METHODS}

\section{Study site}

The study was conducted at the Ecological Reserve of Brazilian Institute of Geography and Statistics (RECOR-IBGE) in Brasília, DF, Brazil (1551'41"S; $\left.47^{\circ} 51^{\prime} 02^{\prime \prime} \mathrm{W}\right)$ within the experimental area of a large fire project. This reserve is 1375 ha large within a slightly hilly landscape $(1130-1160 \mathrm{~m}$ a.s.1.). The mean annual rainfall is $1478 \mathrm{~mm}$ with a well-defined dry season from May to September and a mean annual temperature around $21^{\circ} \mathrm{C}\left(12-29.3^{\circ} \mathrm{C}\right)$. The native vegetation includes the common physiognomic forms of Cerrado of the central Brazilian region: cerradão (70-90\% canopy cover); Cerrado denso (50-70\% canopy cover); cerrado sensu strictu (20-50\% canopy cover); campo sujo ( $<5 \%$ canopy cover) and campo limpo (grassland) (Ribeiro \& Walter 1998). The dominant soil type is a deep well-drained red latosol (oxysol), with high clay content, mostly kaolinite and low cation exchange capacity with moderate acidity ( $\mathrm{pH}$ range: 4.5-6.2). It is derived from Tertiary lateritic deposits (EMBRAPA 1999). In this soil, Ca is a limiting factor for plant growth (Ritchey et al. 1980). The fire project consisted of 30 plots of 4-10 ha, distributed in several Cerrado physiognomies (from grasslands to cerradão woodland) and subjected to different fire regimes or left unburned. In this study the samples were taken from a burned and an unburned plot both 10 ha in a unique vegetation type.

The leaf-cutting ant $A$. laevigata is very common in the study area with large active and abandoned nests. The plots, including active $A$. laevigata nest mounds, are commonly covered with $E$. inflexa grass and S. lycocarpum shrubs. 


\section{Experimental design}

The possible antagonistic effect of fire and $A$. laevigata nests on plant nutrient status was tested using a burned and an unburned plot of $200 \times 500 \mathrm{~m}$ (10 ha) in a Cerrado denso vegetation type. These plots were chosen for sampling because, among those 30 plots in the fire project, they presented the best sampling conditions, such as relatively large ant colonies covered with both E. inflexa and S. lycocarpum and higher densities of these plant species in non-nest areas than other plots. The plots were surveyed from March to April 2004 for mature $A$. laevigata nests $\left(>4 \mathrm{~m}^{2}\right)$, both at the margin of the plot and inside it. The nests were classified as either active or abandoned: active nests were considered those with ants present (most cases), recently cut leaves dropped on the nest-mound, wellmaintained foraging trails, or recent signs of soil disturbance. To avoid great physical and chemical differences among ant nests and subsequent differences on foliar content in plants, only active mature nests were sampled. Thus, the number of replications (ant nests) in each plot was limited but it was compensated by higher homogeneity of the samples. The burned plot had been subjected to prescribed fires every 2 years since 1992. The unburned plot (control) was protected from fire since 1974 (Miranda et al. 1993). Plants from four environments were used: plants on five $A$. laevigata nests in the burned and unburned plots and plants from five points at a minimum distance of $25 \mathrm{~m}$ from ant nests in the burned and unburned plots. A total of 100 apical leaves from 20 $S$. lycocarpum shrubs (five leaves per plant, five plants per treatment) and 100 entire E. inflexa plants (five plants per treatment) were collected. Samples of shrubs were collected in July 2004 (dry season), 2 months after the last prescribed fire. Herbs were collected in October 2004, when post-fire herbs recovery was reached. Leaf samples were dried at $70^{\circ} \mathrm{C}$. Prior to chemical analyses plant material was digested using the micro-Kjeldahl method (Silva 1999). N and $\mathrm{P}$ concentrations were analysed colourimetrically with a continuous flow analyser and the concentrations of $\mathrm{K}, \mathrm{Ca}, \mathrm{Mg}, \mathrm{Al}, \mathrm{S}, \mathrm{Zn}, \mathrm{Fe}, \mathrm{Mn}, \mathrm{Cu}, \mathrm{B}$ were analysed with an Atomic Absorption Spectrophotometer (Silva 1999).

The effect of burning and leaf-cutting ants on plant status was tested using multivariate analyses of variance (MANOVA) with all measured nutrients as dependent variables and the presence of ant nests and fire as fixed independent variables. In case of significant effects in the multivariate test, univariate $F$-tests (ANOVA) were used to identify the specific dependent variables that were significant in the general model. Non-significant factor levels were lumped together using a posteriori contrasts (Crawley 2002).

\section{RESULTS}

Leaf-cutting ants contributed to the significant overall effect of foliar nutrient both for the shrub (MANOVA, Wilks' lambda $=0.082, F=5.08$, d.f. $=12$, $P=0.042$ ) and the herb (Wilks' lambda $=0.065$, $F=6.0$, d.f. $=12, P=0.03)$. There was no significant effect of burning or interaction between ants and burning on nutrient contents for the shrub (MANOVA, Wilks' lambda $=0.28, F=1.27$, d.f. $=12$, $P=0.4$ ) or for the herb (MANOva, Wilks' lambda $=0.15, F=2.81$, d.f. $=12, P=0.063)$. This means that ant nests had a significant effect on nutrient status of the plants whereas burning did not or at least was not evident.

For the shrub species, the proximity of leaf-cutting ant nests resulted in an increase of foliar concentrations of phosphorus $\left(F_{1,18}=9.2, P=0.0076\right)$ and copper $\left(F_{1,18}=11.7, P=0.003\right)$ in the unburned plot as well as of sulphur $\left(F_{1,18}=11.9, P=0.003\right)$ and zinc $\left(F_{1,18}=26.0, P<0.001\right)$ in both plots (Fig. 2$)$. In addition, ant nests in the burned plot led to positive effect on the foliar concentrations of manganese $\left(F_{1,18}=13.3, P=0.002\right)$ and aluminium $\left(F_{1,18}=16.3\right.$, $P<0.001$, Fig. 2). Burning did not directly affect any of the compounds analysed; however, the concentration of phosphorus and copper in plants from nests in the burned plot was lower than those plants from nests in the unburned plot. This suggests that fire had a negative effect on foliar concentrations of these nutrients (Fig. 2). In contrast, burning increased manganese and aluminium concentrations of plants close to ant nests (Fig. 2). There was no significant difference in foliar concentrations of nitrogen $\left(F_{3,16}=1.6, P=\right.$ $0.23)$, potassium $\left(F_{3,16}=2.3, P=0.11\right)$, calcium $\left(F_{3,16}=0.8, P=0.49\right)$, magnesium $\left(F_{3,16}=0.08, P=\right.$ $0.97)$, iron $\left(F_{3,16}=2.3, \quad P=0.11\right)$ and boron $\left(F_{3,16}=1.5, P=0.25\right)$ (Fig. 2).

Concentrations of some nutrients in leaves of herbs were also differently affected by ants and burning (Fig. 3). Ant nests and burning increased foliar nitrogen $\left(F_{1,18}=7.6, P=0.013\right)$, phosphorus $\left(F_{1,18}=4.2, P=0.34\right)$ and potassium $\left(F_{3,16}=9.8\right.$, $P<0.01)$ concentrations. Plants near ant nests had higher potassium concentrations compared with plants away from nests $\left(F_{1,18}=6.0, P=0.02\right.$, Fig. 3$)$. Plants from the burned plot were lower in zinc than plants from the unburned plot $\left(F_{1,18}=5.8, P=0.026\right)$. There was a higher concentration of calcium in plants from ant nests in the unburned plot than in other environments $\left(F_{1,18}=11.6, P=0.003\right)$. In addition, boron was only found in plants from ant nests $\left(F_{1,18}=36.2, P<0.001\right.$, Fig. 3$)$. The combined effect of ants and burning resulted in higher amounts of potassium but lower levels of zinc, calcium and boron (Fig. 3). There was no significant difference in nutrient status of herbs for magnesium $\left(F_{3,16}=2.7, P=0.08\right)$, 


\section{Solanurn lycocarpurn}

Foliar content (dry weigth)
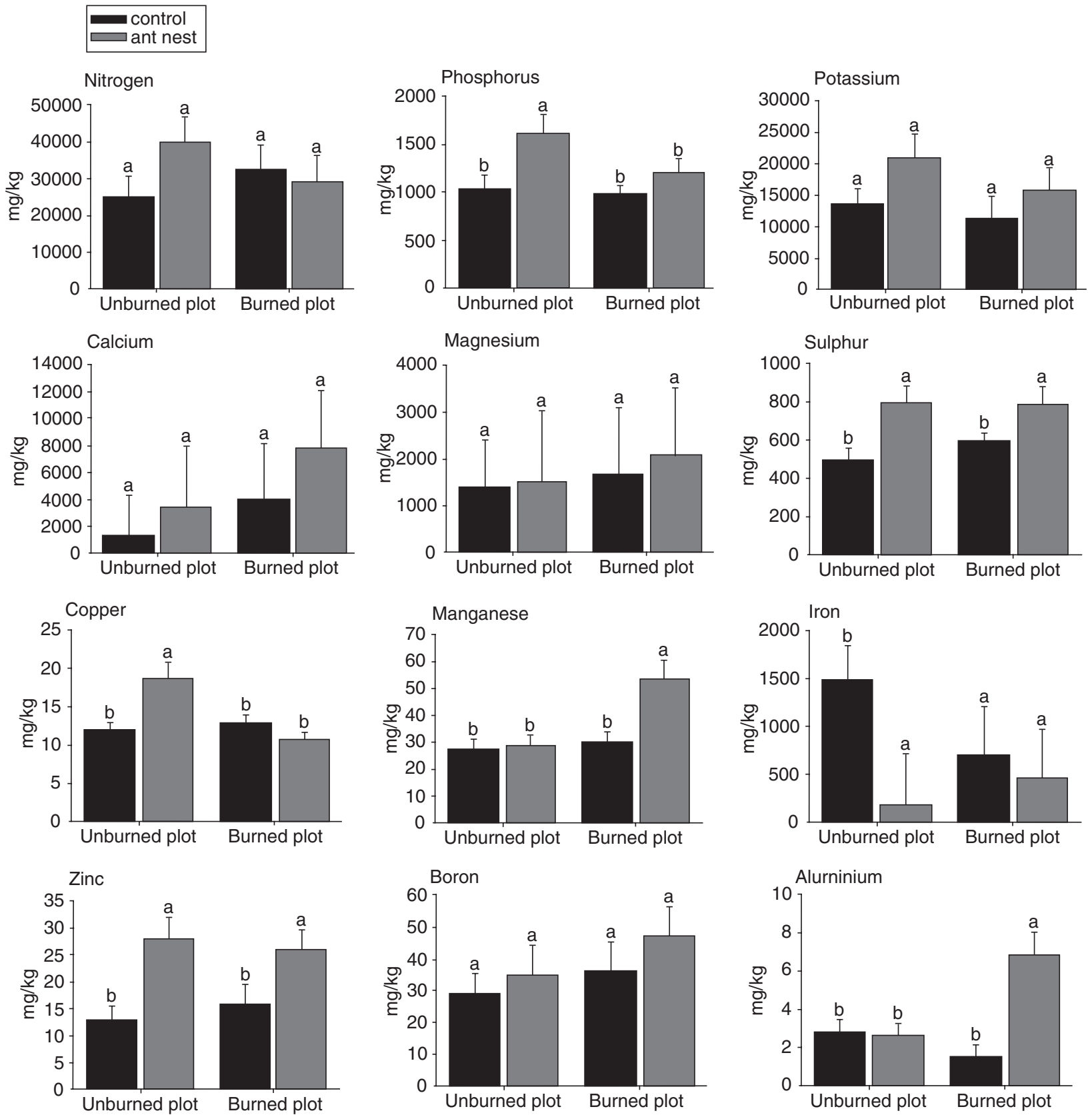

Fig. 2. Foliar contents of the shrub Solanum lycocarpum (Solanaceae) in four different environments: plants on five ant (Atta laevigata) nests in a burned and unburned plot (light bars) and plants from five points at a minimum distance of $25 \mathrm{~m}$ from the ant nests in the same plots (black bars). Different letters above bars indicate a significant difference ( $\alpha=5 \%$, ANOvA with $a$ posteriori contrast). Values are mean $+\mathrm{SE}$.

sulphur $\left(F_{3,16}=1.2, P=0.33\right)$, manganese $\left(F_{3,16}=0.6\right.$, $P=0.65), \quad$ copper $\quad\left(F_{3,16}=1.4, \quad P=0.29\right), \quad$ iron $\left(F_{3,16}=2.40, P=0.11\right)$ and aluminium $\left(F_{3,16}=0.9\right.$, $P=0.44$ ) (Fig. 3). Hence, there is no antagonistic effect of burning and leaf-cutting ants on nutrient status of both plant species. Our results were not as predicted by Coutinho (1984), who expected an increased nutrient concentration in leaves of herbs and 


\section{Echinolaena inflexa}

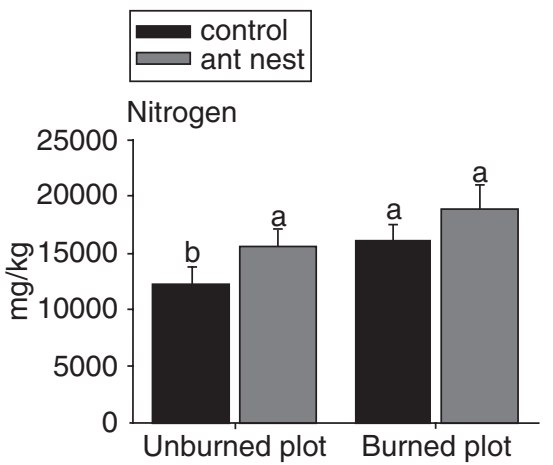

Foliar content (dry weigth)
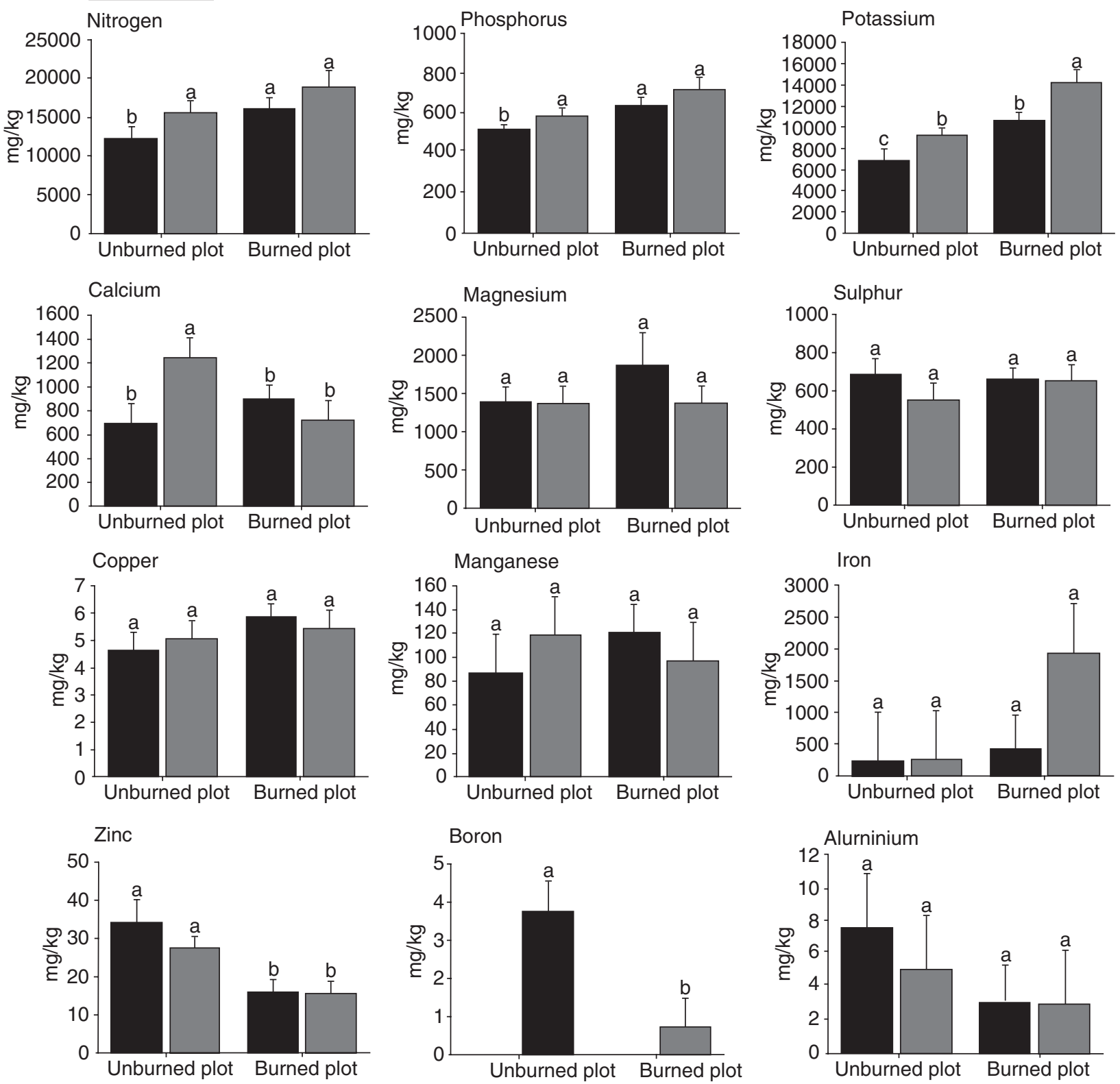

Fig. 3. Foliar contents of the herb Echinolaena inflexa (Poaceae) in four different environments: plants on five ant (Atta laevigata) nests in a burned and unburned plot (light bars) and plants from five points at a minimum distance of $25 \mathrm{~m}$ from the ant nests in the same plots (black bars). Different letters above bars indicate a significant difference ( $\alpha=5 \%$, ANOvA with $a$ posteriori contrast). Values are mean $+\mathrm{SE}$.

a decreased amount of nutrients in the shrubs leaves caused by burning. Instead, in general, the proximity of ant nests resulted in a nutrient increase for both vegetation types and burning had no effects of plant nutrient status (Figs 2,3).

\section{DISCUSSION}

We measured the impact of leaf-cutting ants and burning on plant nutritional contents in the Cerrado and we found that leaf-cutting ant nests might have an 
impact on Cerrado physiognomy, functioning and structure by increasing both macronutrient and micronutrient availability to herbaceous and shrub species, even in the presence of burning. Fire, however, did not affect macronutrient concentrations in the plants studied and had a negative effect on micronutrient contents of herbs. Hence, the hypothesis proposed by Coutinho (1984) that fire ashes could benefit herbs by increasing nutrients was not confirmed. These results, however, should be viewed with caution, because only one herb and one shrub species were used. Although there was great plant diversity in our study site (Moreira 2000), there were few plant species that were found growing from the nest mounds and only $E$. inflexa and S. lycocarpum were found together in all ant nests sampled.

Several studies have been carried out with A. colombica and some Acromyrmex species which deposit their refuse on the soil surface (Haines 1978; Farji-Brener \& Medina 2000; Farji-Brener \& Ghermandi 2004). The effects of nutrient-rich organic refuse produced by these leaf-cutting ant species are easier to detect than those of deposits deep in the ground, typical for leaf-cutting ants species in Cerrado habitats (Coutinho 1984). Therefore, it was necessary to look for indirect evidence of the nutrient enrichment of patches, such as foliar nutrient-contents in plants near ant nests. However, nests of leaf-cutting ants affect the plant community differently when they are active or abandoned (Garrettson et al. 1998; Farji-Brener \& Illes 2000). Active ant nests provide high nutrient availability to the adjacent plants and facilitate root establishment (Moutinho et al. 2003) but support reduced diversity and abundance of plants when compared with non-nest areas or abandoned ant nests (Garrettson et al. 1998). Hence, the study of active ant nests presents some sampling limitations. These limitations may be compensated by studying nests from different regions or physiognomies, such as savannas, grasslands, Cerrado sensu strictu, cerradão and forests. It is evident from this study that any higher nutrient concentration in the soil through biomass mineralization by fire ashes, as found in previous studies (Coutinho 1984; Cook 1994), did not lead to higher assimilation of nutrients in plants. Most eutrophic savannas have an N/P ratio of plant material ranging between 6 and 7 (Van de Vijver et al. 1999). In our study the N/P ratio was between 22 and 33 for herbs and shrubs. This indicates that, as in many other Cerrado systems, phosphorus is a limiting nutrient in our study area. Van de Vijver et al. (1999) suggested there should be increased nutrients in the soil from fire ashes in dystrophic soils, like those of the Brazilian Cerrado. Our results, however, did not confirm this hypothesis, suggesting that any nutrients from ashes are not assimilated by the vegetation we tested, at least not in the period of $60-120$ days after burning.
It has been reported that excessive concentrations of aluminium in plants would reduce the uptake of calcium, phosphorus, manganese, zinc and iron (Foy 1974). Our results, however, shrubs with higher aluminium concentrations from ant nests in the burned plot extracted other cations, such as phosphorus, sulphur, manganese or zinc more efficiently. Plants from ant nests in the burned plot had higher concentrations of these nutrients than shrubs from the burned or control plots (Fig. 2). This suggests that shrubs and woody plants can overcome the possible deleterious effects of aluminium on the uptake and transport of these elements. Alternatively, aluminium in the soil may have had a positive effect on uptake of other nutrients (Hackett 1962). Haridasan (1982) also found a positive correlation among foliar aluminium concentrations with levels of calcium, magnesium and zinc in plants from a Brazilian Cerrado near our study site.

Farji-Brener and Silva (1995) found a higher soil concentration of calcium in ant nests of $A$. laevigata than in adjacent soil, in a Venezuelan savanna. The higher calcium content in the herbs from unburned nests in our study indicates that $A$. laevigata nests act in the biogeochemical cycling of nutrients, promoting plant growth by increase of both soil fertility and foliar nutrient content. The importance of A. laevigata on Cerrado vegetation is high if we consider that (i) $\mathrm{P}$ and $\mathrm{Ca}$ are limiting factors in these soils (Ritchey et al. 1980); (ii) the nest durability and persistence (estimates range from 10 to 20 years) even after death of the colony allows the plant community to exploit each 'ant oasis' for long time (Coutinho 1984); and (iii) there is a relatively high turnover rate of leaf-cutting ant nests (Perfecto \& Vandermeer 1993). Perfecto and Vandermeer (1993) estimated the size and turnover rate of $A$. cephalotes nests in a tropical forest and suggested that the ant nests could occupy the equivalent of the entire forest area every 200-300 years. The total area covered by nest mounds in our study site was considerable $(0.55 \%$ in unburned plot and $1.1 \%$ in the burned plot). Considering the total area covered by leaf-cutting ants in many Neotropical environments, the positive effects of their nests could have farreaching impacts on the plant community of Cerrado.

The factors responsible for higher foliar nutrient concentrations in plants from ant nests are not yet fully understood. Schoereder and Howse (1998) analysed the effect of nest distance on foliar content in various woody species of the Cerrado and did not find a positive effect of nest on plants close to the nests. These authors, however, did not consider variation in nutrient content among plant species (Haridasan 1982; Malavolta et al. 1997); hence, variation among plant species could have masked any positive effects of ant nests. This hypothesis was confirmed because in our study $S$. lycocarpum and E. inflexa also varied in levels 
of essential nutrients (Figs 2,3). An alternative explanation for higher foliar nutrient concentrations in plants is that, together with organic matter accumulation, ant nests promote a reorganization of soil microaggregates, facilitating soil solution assimilation by roots (rhyzosphere). It would therefore be interesting to assess whether root density inside Atta nests is higher and if there are differences in soil microstructure in ant nests compared with adjacent soil.

In conclusion, it is possible that leaf-cutting ants play an important role in biogeochemical cycling in the Cerrado ecosystem through concentrating nutrients in plants near the nests. In contrast, burning did not result in any significant increase in the accumulation of nutrients by the studied plants, nor did it result in any significant losses. Therefore, leaf-cutting ants are important actors in ecosystem processes and possibly affect plant species composition, at least on a local scale. The low concentration of nutrients in control plots and high nutrient concentration in plants near ant nests suggest that plants of Cerrado are adapted to the low-soil fertility and seasonal burning but they can respond to higher nutrient soil conditions promoted by leaf-cutting ant nests. Nests of $A$. laevigata should accelerate vegetation recovery after burning and could affect the plant structure in Cerrado ecosystem if the balance between its negative effect via herbivory and its positive effect via the enrichment of soil nutrients is positive.

\section{ACKNOWLEDGEMENTS}

The authors wish to thank Eraldo Lima for important suggestions on previous experiment design; Washington Silva, Danival Souza and Túlio Gomes for field assistance; Maria Iracema Gonzales, Betânia and Mirian for providing us with all facilities at RECOR reserve; Arne Janssen (Visiting Teacher [PVE] from CAPES, Brazil) for helpful suggestions and English revision; Renata Campos, Teresa Gonçalves for comments on previous versions of this manuscript; The Nature Conservancy (project 024/2003) and FAPEMIG for financial support. The authors are supported by CNPq (Conselho Nacional de Pesquisa e Desenvolvimento).

\section{REFERENCES}

Autuori M. (1947) Contribuição para o conhecimento da saúva (Atta spp.).VI - O sauveiro depois da primeira revoada (Atta sexdens rubropilosa Forel, 1908). Arq. Inst Biol. São Paulo 18, 39-70.

Batmanian G. J. \& Haridasan M. (1985) Primary production and accumulation of nutrients by the ground layer community of cerrado vegetation of central Brazil. Plant Soil 88, $437-40$.
Cook G. D. (1994) The fate of nutrients during fires in a tropical savanna. Aust. F. Ecol. 19, 359-65.

Coutinho L. M. (1978) O conceito de cerrado. Rev. Bras. Bot. 1, $17-23$.

Coutinho L. M. (1984) Aspectos ecológicos da saúva no cerrado. A saúva, as queimadas e sua possível relação na ciclagem de nutrientes minerais. Bol. Zool. Univ. São Paulo 8, 1-9.

Coutinho L. M. (1990) Fire in the ecology of the Brazilian Cerrado. In: Fire in the Tropical Biota - Ecosystem Processes and Global Challenges (ed. J. G. Goldammer) pp. 82-105. Ecological Studies Vol. 8A. Springer-Verlag, Berlin.

Crawley M. J. (2002) Statistical Computing: An Introduction to Data Analysis Using S-Plus. John Wiley \& Sons, New York.

Crutzen P. \& Andreae M. O. (1990) Biomass burning in the tropics: impact on atmospheric chemistry and biogeochemical cycles. Science 250, 1669-78.

Eiten G. (1972) The cerrado vegetation of Brazil. Bot. Rev. 38, 201-341.

EMBRAPA - Empresa Brasileira de Pesquisa Agropecuária (1999) Sistema Brasileiro de Classificação de Solos. CNPS, Brasília.

Farii-Brener A. G. \& Ghermandi L. (2004) Seedling recruitment in a semi-arid Patagonian steppe: facilitative effects of refuse dumps of leaf-cutting ants. F. Veg. Sci. 15, 823-30.

Farji-Brener A. G. \& Illes A. E. (2000) Do leaf-cutting ant nests make 'bottom-up' gaps in neotropical rain forests?: a critical review of the evidence. Ecol. Lett. 3, 219-27.

Farji-Brener A. G. \& Medina C. A. (2000) The importance of where to dump the refuse: Seed banks and fine roots in nests of the leaf-cutting ants Atta cephalotes and A. colombica. Biotropica 32, 120-6.

Farji-Brener A. G. \& Silva J. (1995) Leaf-cutting ants and forest groves in a tropical parkland savanna of Venezuela: facilitated succession? F. Trop. Ecol. 11, 651-69.

Foy C. D. (1974) Effects of aluminium on plant growth. In: The Plant Root and its Environment (ed. E. W. Carson) pp. 60142. University Press of Virginia, Charlottesvile.

Garrettson M., Stetzel J. F., Halpern B. S., Hearn D. J., Lucey B. T. \& McKone M. J. (1998) Diversity and abandance of understorey plants on active and abandoned nests of leaf-cutting ants (Atta cephalotes) in a Costa Rican rain forest. F. Trop. Ecol. 14, 17-26.

Hackett C. (1962) Stimulative effects of aluminium on plant growth. Nature 195, 471-2.

Haines B. L. (1978) Element and energy flows through colonies of the leaf-cutting ant, Atta colombica, in Panama. Biotropica $10,270-7$.

Haridasan M. (1982) Aluminium accumulation by some cerrado native species of central Brazil. Plant Soil 65, 265-73.

Hölldobler B. \& Wilson E. O. (1990) The Ants. Harvard University Press, Cambridge.

Jonkman J. (1978) Nests of the leaf-cutting ant Atta vollenweideri as accelerators of succession in pastures. Zeit. Ang. Entom. $86,25-34$.

Kauffman J. B., Cummings D. L. \& Ward D. E. (1994) Relationships of fire, biomass and nutrient dynamics along a vegetation gradient in the Brazilian cerrado. F. Ecol. 82, 519-31.

Lugo A., Farnworth E., Pool D., Jerez P. \& Kaufman G. (1973) The impact of the leaf-cutting ant Atta colombica on the energy flow of a tropical wet forest. Ecology 54, 1292301.

Malavolta E., Vitti G. C. \& Oliveira S. A. (1997) Avaliação do estado nutricional das plantas: princípios e aplicações. Piracicaba, Pofatos. 
Miranda A. C., Miranda H. S., Dias I. F. O. \& Dias B. F. S (1993) Soil and air temperatures during prescribed cerrado fires in Central Brazil. F. Trop. Ecol. 9, 313-20.

Moreira A. G. (2000) Effects of fire protection on savanna structure in Central Brazil. F. Biogeogr. 27, 1021-9.

Moutinho P., Nepstad D. C. \& Davidson E. A. (2003) Influence of leaf-cutting ant nests on secondary forest growth and soil properties in Amazônia. Ecology 84, 1265-76.

Perfecto I. \& Vandermeer J. (1993) Distribution and turnover rate of a population of Atta cephalotes in a tropical rain forest in Costa Rica. Biotropica 25, 316-21.

Radho-Toly S., Majer J. D. \& Yates C. (2001) Impact of fire on leaf nutrients, arthropod fauna and herbivory of native and exotic eucalypts in Kings Park, Perth, Western Australia. Aust. Ecol. 26, 500-6.

Ribeiro J. F. \& Walter B. M. T. (1998) Fitofisionomias do bioma cerrado. In: Cerrado Ambiente E Flora (eds S. M. Sano \& S. P. Almeida) pp. 89-168. EMBRAPA, Planaltina.

Ritchey K. D., Souza D. M. J., Lobato E. \& Correa O. (1980) Calcium leaching to increase rooting depth in a Brazilian savanna oxisol. Agron. F. 72, 40-4.
Schoereder J. H. \& Coutinho L. M. (1990) Fauna e estudo zoossociológico das espécies de saúvas (Formicidae: Attini) de duas regiões de cerrado do Estado de São Paulo. Rev. Bras. Entom. 34, 561-8.

Schoereder J. H. \& Howse P. E. (1998) Do trees benefit from nutrient-rich patches created by leaf-cutting ants? Stud. Neotrop. Fauna Environ. 33, 111-15.

Silva F. C. (1999) Manual de analises quimicas de solos, plantas e fertilizantes. EMBRAPA, Brasília.

Van de Vijver C. A. D. M., Poot P. \& Prins H. H. T. (1999) Causes of increased nutrient concentrations in post-fire regrowth in an East African savanna. Plant Soil 214, 17385.

Vasconcelos H. L. \& Cherrett J. M. (1995) Changes in leafcutting ant populations (Formicidae: Attini) after the clearing of mature forest in Brazilian Amazônia. Stud. Neoropt. Fauna Environ. 30, 107-13.

Verchot L. V., Moutinho P. R. \& Davidson E. A. (2003) Leafcutting ant (Atta sexdens) and nutrient cycling: deep soil inorganic nitrogen stocks, mineralization, and nitrification in Eastern Amazonia. Soil Biol. Biochem. 35, 1219-22. 